\title{
The genera Isopterygium Mitt. (Bryopsida, Hypnaceae) and Isopterygiopsis (Hedw.) Z.Iwats. (Bryopsida, Plagiotheciaceae) in Australia
}

\author{
Zen Iwatsuki' \& Helen P. Ramsay² \\ ${ }^{1}$ The Hattori Botanical Laboratory, Okazaki Branch 10-3, Okazaki-shi, Aichi-ken 4440846, Japan \\ ${ }^{2}$ National Herbarium of New South Wales, Royal Botanic Gardens, Sydney 2000 New South Wales, \\ Australia
}

\begin{abstract}
A revision of the genus Isopterygium in Australia has resulted in recognition of only one species, I. albescens in Australia. Of the other species listed for the genus in this country, Isopterygium minutirameum, I. novae-valesiae and a number of other recorded names have been placed into synonymy with $I$. albescens. Isopterygium arachnoideum and I. subarachnoideum have been transferred to Isopterygiopsis pulchella. The presence of Isopterygiopsis pulchella (Schimp.) Z.Iwats. in Australia (considered doubtful by Streimann \& Klazenga 2002) is confirmed and the types for Australian species of Isopterygium arachnoideum, and I. subarachnoideum are placed into synonymy with it. Isopterygium albescens is considered to be a member of the family Hypnaceae while Isopterygiopsis pulchella is in the Plagiotheciaceae.
\end{abstract}

Pseudotaxiphyllum pohliicarpum (Hypnaceae) is recorded as a new species for Australia.

\section{Introduction}

Prior to Iwatzuki's studies $(1970,1987)$, the genus Isopterygium contained more species, was very heterogeneous and had been placed variously in the Hypnaceae or Plagiotheciaceae. Iwatsuki transferred various species into a number of new genera, e.g., Pseudotaxiphyllum, Isopterygiopsis, Herzogiella, and Taxiphyllum, most of which are now included in the family Hypnaceae. The diagnostic characters for these new genera are based on morphological criteria such as absence of pseudoparaphyllia, the location and surface of rhizoids, size and wall of epidermal and cortical stem cells, type of propagules and presence or absence of an annulus (see Iwatsuki 1970: table 3, p. 339; Iwatsuki 1987: fig 1, p. 446 \& table 1, p. 450).

Isopterygium was included in the new family Pylasiadelphaceae created by a division of Sematophyllaceae s. l. by Goffinet and Buck (2004) in their recent interpretation of moss classification. As Isopterygium does not have a number of the characters that define the Pylasiadelphaceae, e.g., the alar cells enlarged and coloured and rostrate operculum, we do not agree with this placement and have returned Isopterygium to the family Hypnaceae. 

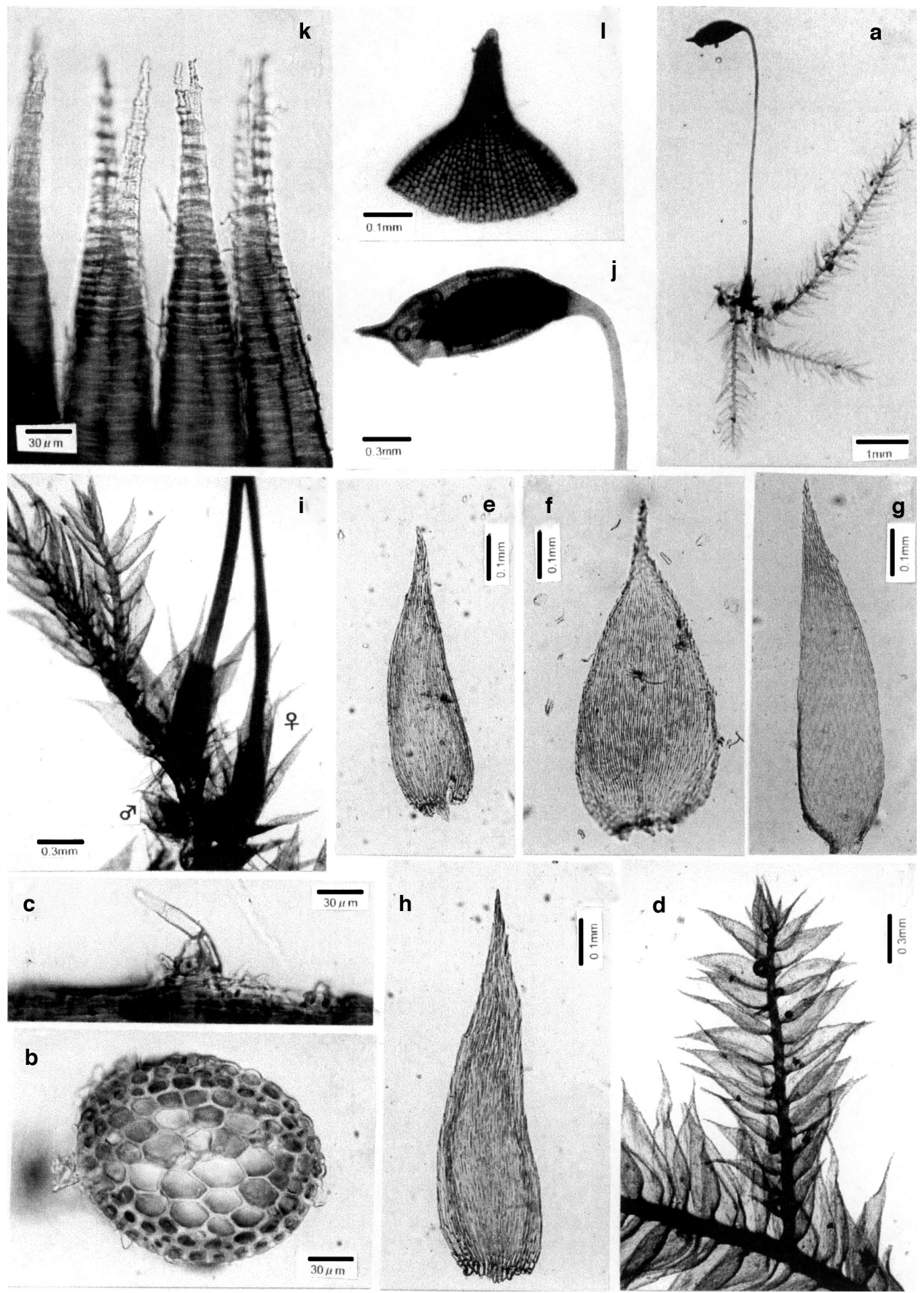

Fig. 1. Isopterygium albescens. a, plant with a sporophyte; $\mathbf{b}$, cross-section of branch; $\mathbf{c}$, filamentous pseudoparaphyllia; $\mathbf{d}$, branch with leaves; $\mathbf{e}-\mathbf{h}$, variation of leaves; $\mathbf{i}$, sporophytes; $\mathbf{j}$, capsule with operculum; k, peristome teeth; l, operculum. (all figs based on Australian collections; a, j, k \& 1 Schafer-Verwimp 3862, CANB; b-d, f Brock 557, CANB; g lectotype of I. novaevalesiae, Watts 1902, NSW; e, h, j Streimann 45351, CANB; photographs by Z. Iwatsuki). 
The genus Isopterygium contains more than 200 taxa of which 11 names are recorded for Australia, including five endemics (Streimann \& Klazenga 2002). Present studies have reduced the total species number in Australia for Isopterygium to one, and two of the previously listed endemic species known from types or only a few collections, have been determined as Isopterygiopsis pulchella.

The other recorded species, Isopterygium limatum, found in New Zealand (Fife 1985) and Australia (Streimann \& Klazenga 2002), has been under investigation since it lacks the rostrate operculum, has a well-differentiated annulus, different pseudoparaphyllia, as well as characters such as axillary papillose rhizoids that are not present in Isopterygium. Based on studies of Australian, New Zealand and subantarctic (including Macquarie Island, Seppelt 2004) material, this taxon has been placed in a new genus Austrohondaella (Iwatsuki et al. 2009), which has been placed in the Hypnaceae. Isopterygium acuminatum and I. amblyocarpum are considered synonymous with it.

\section{Isopterygium}

Isopterygium Mitt., J. Linn. Soc. Bot. 12: 21 (1869).

Lectotype: Hypnum tenerum Sw. = Isopterygium tenerum (Sw.) Mitt. selected by Z. Iwatsuki \& M. Crosby, J. Hattori Bot. Lab. 45: 389-393 (1979).

Etymology: from the Greek isos (equal), pteryx (wing like) and ion (diminutive suffix) in reference to the delicate wing like leaf arrangement.

Defining characters for the identification of Isopterygium (Iwatsuki 1987) include leaves ovate to ovate-lanceolate; leaf apices more or less serrulate; costa short and double or absent; rhizoids smooth, rarely scabrous, originating below and between leaf insertions not in leaf axils; epidermis of normal small cells, outer cortical stem cells small and thick-walled forming a sclerodermis, central strand lacking; propagules when present, filamentous or short; sporophytes almost uniform being hypnaceous (diplolepidous) but with absence of annulus, with non-collenchymatous exothecial cells and a short rostrate operculum. Several filamentous pseudoparaphyllia are usually seen around a branch primordium in Isopterygium. When a branch primordium grows into a branch a few more or less triangular leaves develop first, occurring at the base of young branches, and primordia are also present on the main stems surrounding the triangular leaves.

Chromosome numbers, summarised here and obtained from Fritsch (1991) and Goldblatt and Johnson $(1994,1998,2003)$ are available for several species of Isopterygium (North America, $\mathrm{n}=11,22,12(11+\mathrm{m})$; Europe, $\mathrm{n}=12(11+\mathrm{m})$; Japan, $\mathrm{n}=11,12$; India, $\mathrm{n}=11(10+\mathrm{m}), 12,22$, but none is available for Australian populations.

Isopterygium albescens (Hook.) A.Jaeger, Ber. Thatigk. St. Gallischen Narwiss. Ges. 1876-77: 433 (1878). Hypnum albescens Hook. in Schwägr., Sp. Musc. Suppl. 3(1): 226b,Tab. CCXXV1. b (1828).

Type: In regno Nepal Indiae lectum dedit Pr. Hooker.

Isopterygium latifolium Broth., Oefv. Finsk. Vetensk. Soc. 42:114 (1900), syn. nov. Type: Australia, New South Wales: Alstonville Road, Ballina, W.W. Watts 211, holotype: NSW; isotype: H-BR, MEL 59608). 
Isopterygium howeanum Broth. \& Watts, Proc. Linn. Soc. New South Wales 40: 380-381 (1915) , syn. nov. Type: Hillside, back of Johnsons, Lord Howe Island. W.W. Watts 112, 8.vii.1911 holotype: (NSW); isotype: (H-BR).

Hypnum candidum Müll.Hal., Linnaea 35: 624 (1868) , syn. nov. Type: Australia, New South Wales, Ash Island, Hunter River, Mrs E. Ford (MEL 59547). Isopterygium candidum (Müll.Hal.) A.Jaeger, Ber. Thätigk. St. Gallischen Naturwiss. Ges. 1876-77: 437 (1878) (Gen. Sp. Musc. 2:4503), fide J. H. Willis, Victorian Naturalist 71: 161 (1955).

Hypnum molliculum Sull., Proc. American Academy of Arts and Sciences 3:78 (1854). Type: Hawaii, Mauna Kea, Wilkes (BM). Isopterygium molliculum (Sull.) Mitt. in Seem., Fl. Vit. 399 (1873), fide Dixon Proc. Linn. Soc. New South Wales 55: 295 (1930).

Isopterygium sublatifolium Broth., Proc. Linn. Soc. New South Wales 43: 564 (1918), nom. nud. in synon.

Hypnum minutirameum Müll.Hal., Syn. Musc. Frond. 2: 689 (1851); Bryol. Jav. II, p. 191, Tab. 290 (1808), syn. nov. Type: Java: Blume, in Herb. Al. Braun, syn. nov. Isopterygium minutirameum (Müll.Hal.) A.Jaeger, Ber. Thätigk. St. Gallischen Naturwiss. Ges. 1876-77: 434 (1878). Taxiphyllum minutirameum (Müll.Hal.) H.A.Mill. \& D.R.Smith, Micronesica 4: 225 (1968).

Hypnum norfolkianum Müll.Hal., Linnaea 37: 160 (1872). Type: Norfolk Insula. Ferd. Muller mixed with Rhacopilum convolutaceum. holo: BM (Hampe); isotype: NY. Isopterygium norfolkianum (Müll.Hal.) A.Jaeger, Ber. Thätigk. St. Gallischen Naturwiss. Ges. 1876-77: 435 (1878), fide Streimann (2002), p.100-101.

Isopterygium baileyanum Müll. Hal. ex F.M. Bailey, Syn. Queensland Fl. Suppl. 2: 71 (1888). nom. nud. in synon. Based on: Qld: Kedron Brook and Port Curtis F.M. Bailey (BRI).

Isopterygium amoenum Broth., Oefvers. Finska Vetensk. Soc. Foerh 42: 112 (1900), syn. nov. Type: Australia, New South Wales: Richmond River, W.W. Watts, n. 802, 888, lectotype: HBR (Watts 888), isolectotype: NSW (Watts 888) [selected here]; syn: H-BR(Watts 802), isosyntypes: MEL, NSW (Watts 802).

Isopterygium neocaledonicum Thér., Bull. Acad. Int. Géogr. Bot. 19: 23 (1909), syn. nov. Type: New Caledonia, Rivière Carricouyé, Franc (BM).

Isopterygium viridepallens Müll.Hal. ex Burges, Proc. Linn. Soc. New South Wales, 60: 93 (1935). nom. nud. in synon. Based on: N.S.W. Gosford W. Forsyth 442, 19.ix.1891; Lane Cove W. Forsyth 497, National Park W. Forsyth 492 (NSW).

Isopterygium minutirameum f. brevifolium M.Fleisch. Die Musci der Flora von Buitenzorg 4: 1427. 1923. Taxiphyllum minutirameum (Müll.Hal.) H.A.Mill. \& D.R.Smith var. brevifolium (M.Fleisch.) H. Whittier, Florida Scientist 38: 103 (1975).

Hypnum austropusillum Müll.Hal., Linnaea 37: 159 (1872). Type: Qld: Brisbane River, Dietrich. (BRI). Isopterygium austropusillum (Müll.Hal.) A.Jaeger, Ber. Thätigk. St. Gallischen Naturwiss. Ges. 1876-77: 435 (1878). (Gen. Sp. Musc. 2: 501).

Isopterygium austrosubulatum Müll.Hal. ex Burges, Proc. Linn. Soc. New South Wales 60: 93 (1935), nom. nud. in synon. A Watts specimen bearing this name is held at NY (W. Buck, pers. comm.): W.W. Watts 1586, Sep 1897 (n.v.). 
Isopterygium novae-valesiae Broth., Oefv. Finska Vet. Soc. Foerh. 42: 113 (1900), syn. nov. Type: Australia, New South Wales : Richmond River, Fernleigh, W.W. Watts 1902, lectotype [selected here]: H-Br, isolectotype: NSW. From the original list of types the following become residual syntypes -. New South Wales, Richmond River, Fernleigh, W.W. Watts (n. 1384, 1399, 1403, 1900); Pearces Creek (1395, 1408); Teven (1430 ex. p.) Alstonville (470); Uralba (1801), all held H-BR, NSW, except for Watts 1395 (which at NSW is a poor specimen, not Isopterygium).

Illustrations: Dozy \& Molkenboer, Bryologia Javanica, vol II, p. 193, tab. CCXC, (1868), as Hypnum; Bartram, Mosses of the Philippines, plate 27, fig. 474 (1939). Gangulee, Mosses of Eastern India and Adjacent Regions 7: 1960, fig 1007 (1979). Noguchi, Illustrated Moss Flora of Japan 5: 1051, fig. 462A (1994).

Plants autoicous, slender, small to medium-sized, in pale yellow-green, grey-green to green, slightly glossy prostrate mats. Stems creeping, irregularly pinnately branched, to $6.0 \mathrm{~cm}$ long. In cross-section, stem without central stand, and the cortex with 2 outer layers of firm-walled cells. Pseudoparaphyllia filamentous. Branches short, ascending, often loosely foliated. Rhizoids smooth, red, sparsely developed on underside of stem between leaves. Branches suberect, simple or with branchlets $1.0-1.5 \mathrm{~cm}$. Leaves ovate,

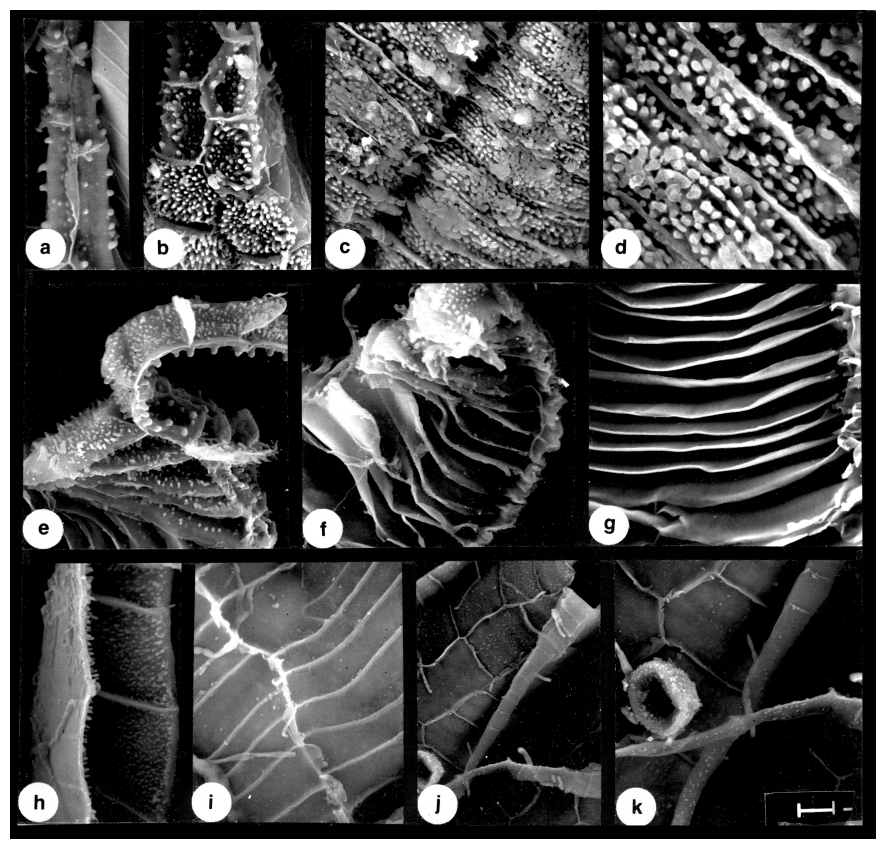

Fig. 2. Scanning electron micrographs of the peristome of Isopterygium albescens (as I. novaevalesiae. a, close view of apex of exostome tooth; $\mathbf{b}$, tooth below apex showing papillose surface; $\mathbf{c} \& \mathbf{d}$, pattern of lamellae and papillae between, on abaxial surface in lower part of tooth; e, side view of exostome tooth near apex curled over showing lamellae; $\mathbf{f}$, closer view of lamellae in base of mid tooth; $\mathbf{g}$, lamellae towards base of tooth, smooth no papillae; $\mathbf{h}$, abaxial view of endostome segment near apex; $\mathbf{i}$, abaxial view of basal membrane with smooth surface; $\mathbf{j}$, cilia curved back over basal membrane; k, spore, cilium and basal membrane behind. [H.P. Ramsay 181115 (NSW).] Scale bar a, b, e, g, h, $\mathrm{k}=20 \mu \mathrm{m} ; \mathrm{c}, \mathrm{f}, \mathrm{i}=10 \mu \mathrm{m} ; \mathrm{j}=100 \mu \mathrm{m}$. [ SEM's prepared by Meera Jayachandran at University of New South Wales.] 


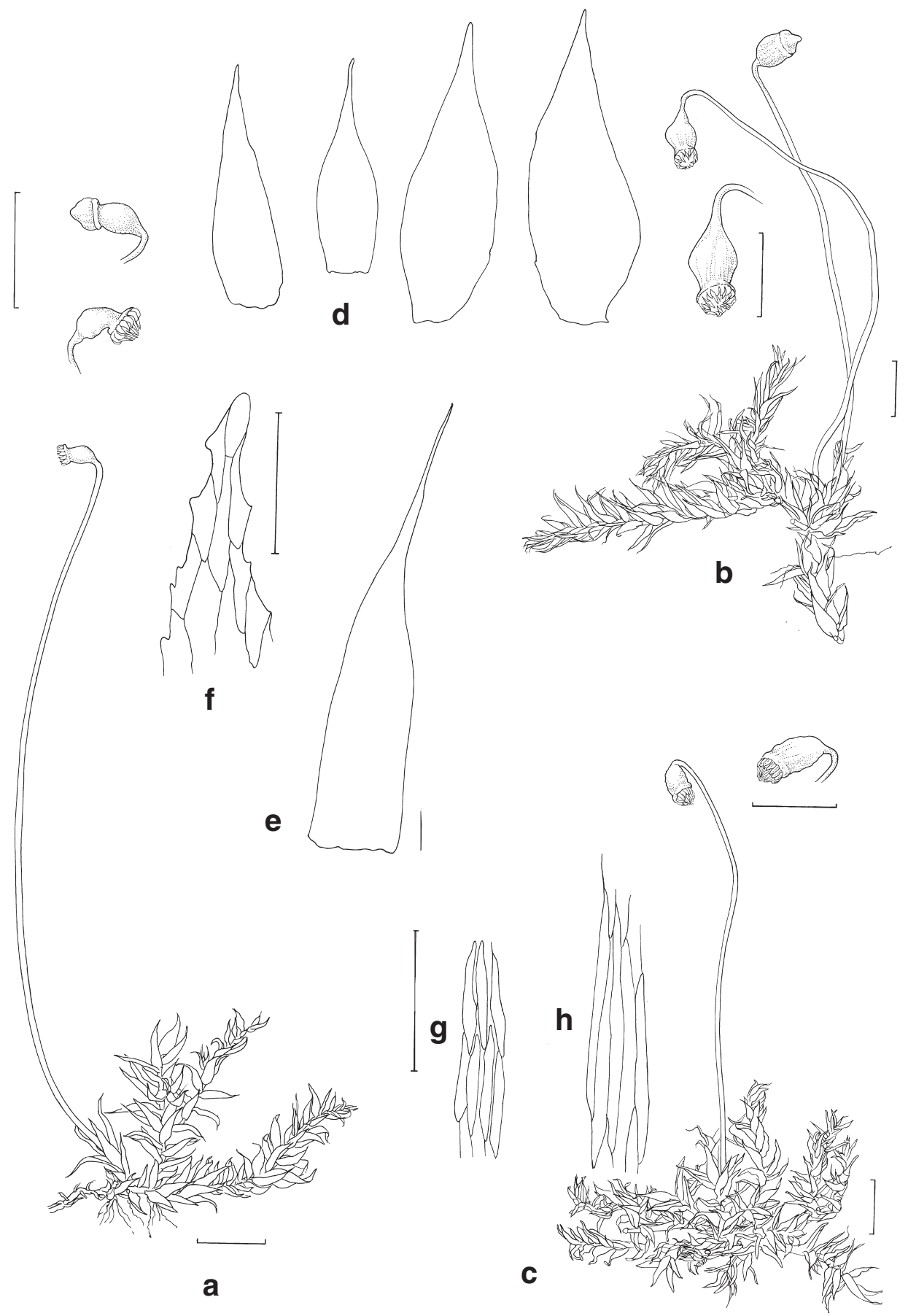

Fig. 3. Illustrations showing variation in Isopterygium albescens in Australia. a, habit with capsules (as Isopterygium novaevalesiae, isolectotype, Watts 1902, NSW); b, habit with capsules (as Isopterygium minutirameum, Watts 4584, NSW); c, habit with capsules (as Isopterygium albescens, Watts 235, NSW); d1-4, variation in leaves: d1 stem leaf, d2-d4 branch leaves; e, perichaetial leaf; f, apical leaf cells; g, upper leaf cells; h, midleaf cells. (Drawings by: D. Mackay (habit of I. novaevalesiae), C. Wardrop \& H.P. Ramsay). Scale bars: $1.0 \mathrm{~mm}$ for habits and leaves; $100 \mu \mathrm{m}$ for cellular drawings. 
ovate-lanceolate or lanceolate, usually slightly concave, erect-patent, $0.6-1.2 \times 0.28-$ $0.35 \mathrm{~mm}$, asymmetrical, margins entire or obscurely serrate or denticulate above, apex gradually acuminate to a slenderly tapering narrow acumen, slightly falcate towards ends of branches. Laminal cells in midleaf narrow, 70-100 $\times 4-8 \mu \mathrm{m}$, linear to vermicular; apical cells short rhomboid (4:1); cells in alar region consisting of 2-3 small thick walled, shortly rectangular or irregularly shaped hyaline cells, basal row of subrectangular cells. Perigonia on branches and lower parts of stems, rounded budlike. Perichaetia on stems, inner perichaetial leaves gradually long acuminate. Calyptra smooth, cucullate $1.0 \mathrm{~mm}$ long. Seta long-exserted, $0.6-1.2 \mathrm{~cm}$, pale red; capsules frequently produced, oblongovoid, curved, horizontal or pendulous, operculum bluntly curved-rostrate; peristome double, exostome teeth 16, endostome 16, same length as exostome, with single cilium as long as segments. Spores 9-13 $\mu \mathrm{m}$, finely papillose. Figs. 1-4

Distributed in Himalayas, Malesia, and tropical and subtropical Asia as far north as Japan, on Pacific Islands, in New Zealand and Australia. Specimens collected by W.W. Watts on Lord Howe Island as Isopterygium howeanum or I. candidum are I. albescens. With the transfer to Isopterygiopsis of Isopterygium pulchellum and the exclusion of I. limatum from the genus (Iwatsuki et al. 2009), distribution of Isopterygium in Australia is confined to the mainland chiefly in coastal regions from tropical northern Western Australia, Northern Territory and Queensland south to New South Wales and Victoria.
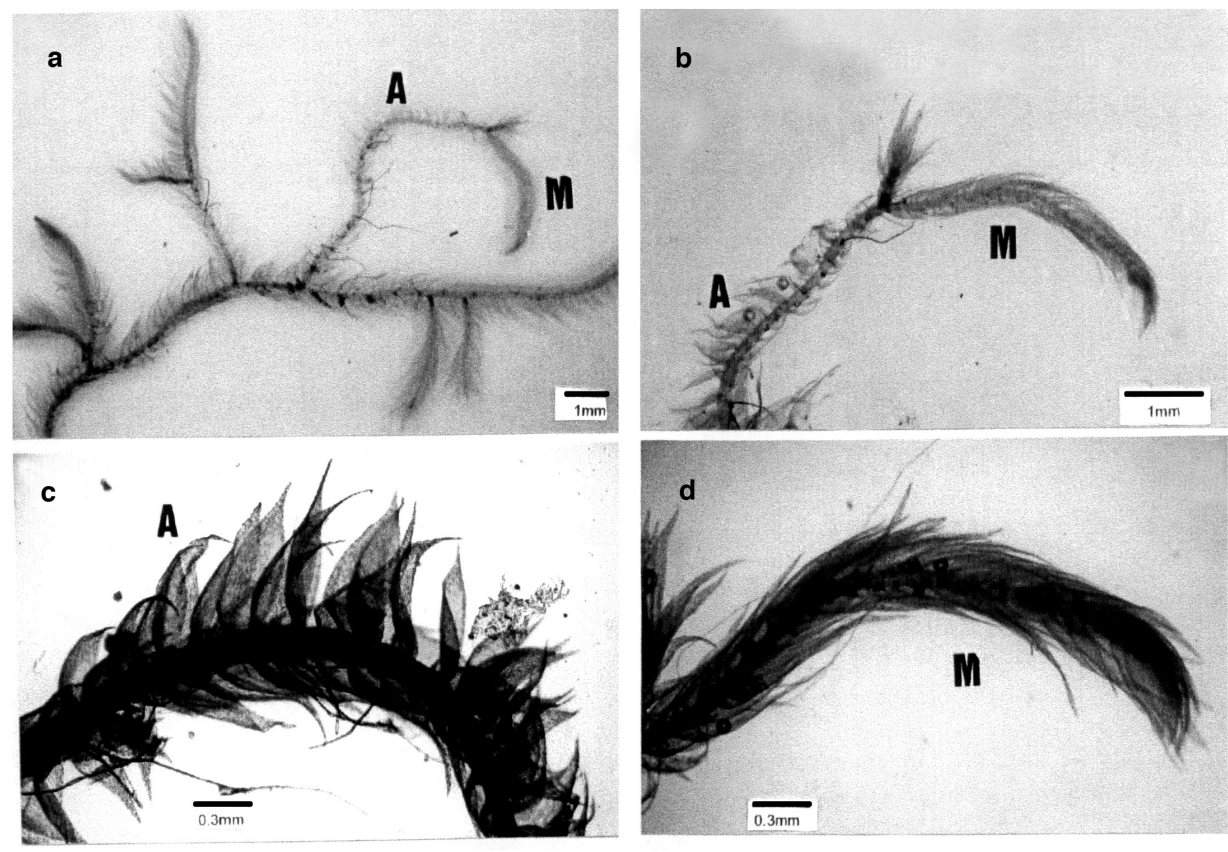

Fig. 4. Isopterygium albescens, showing variation of leaves. a, b, part of plant showing two types of leaves (A shows ovate to ovate-lanceolate leaves, $\mathrm{M}$ shows lanceolate leaves); $\mathbf{c}$, part of branch with ovate to ovate-lanceolate leaves (plants with this type of leaves have been called Isopterygium albescens); d, branch with lanceolate leaves (plants with this type leaves have been called Isopterygium minutirameum). (all from Russell-Smith 6200, CANB; photographs by Z. Iwatsuki). 
Dalton et. al. (1991) noted that I. albescens had been listed for Tasmania although Scott and Stone (1976) recorded it only from the mainland. Streimann and Klazenga (2002) have listed I. albescens for Tasmania but no specimens have been located by us. The genus is thus absent from the temperate regions of southern Western Australia, South Australia and Tasmania. Fig. 5

Selected specimens. Western Australia: Galvin Gorge, G. Kantak \& S.P. Churchill 687 (NY, NSW); Northern Territory: Kakadu, L.A. Craven \& G. Whitbread 6801 (CANB); Wangi Road, Walker Creek 68 km SSW of Darwin, H. Streimann 8814 (CANB); Katherine Gorge, G.E. Kantak 696 (CANB). Queensland: Babinda, W.W. Watts Q300 (NSW); Malanda, W.W. Watts 577 (NSW); Cairns, W.W. Watts 235 (NSW). New South Wales: Manning River, E. Cheel 485 (NSW); Pimlico, Richmond River, W.W. Watts 432 (NSW); Alstonville Road, Alstonville, W.W. Watts 612 (NSW); Wardell Road, Richmond River, W.W. Watts 687 (NSW); Stanwell Park, W.W. Watts 8267 (NSW); Lord Howe Island, north end of island in closed rainforest, D.H. Vitt 28327 (NSW). Victoria: Dandenongs, East Gippsland, E. Ronfield s.n. (MEL).

We had much difficulty in identifying and separating specimens of I. albescens and I. minutirameum, because these two species are extremely variable in shape and colour of leaves. Isopterygium albescens and I. minutirameum are usually distinguished as follows:

1. Plants often whitish, leaves ovate to ovate-oblong

I. albescens

1. Plants not whitish, leaves lanceolate, slenderly tapering to a narrow acumen

I. minutirameum

However, the above key does not work well for many specimens of Isopterygium in Asia or Australia. Recently, we found a very interesting specimen which has two types of leaves on one plant. The specimen had been determined as I. minutirameum (Northern Territory, Butterfly Springs, J. Russell-Smith 6200, CANB). As shown in Fig. 4 some branches (marked by M) have leaves defined in the key as I. minutirameum, and some other branches (marked by A) have leaves defined in the key as I. albescens. Identifications of specimens of I. albescens and I. minutirameum have often been changed from I. albescens to I. minutirameum or vice versa. For these reasons, we reduce I. minutirameum to a synonym of I. albescens. In North America, Isopterygium tenerum, which is related to our I. albescens, is also extremely variable and includes two types of leaves comparable to those of I. albescens and I minutirameum. These variants
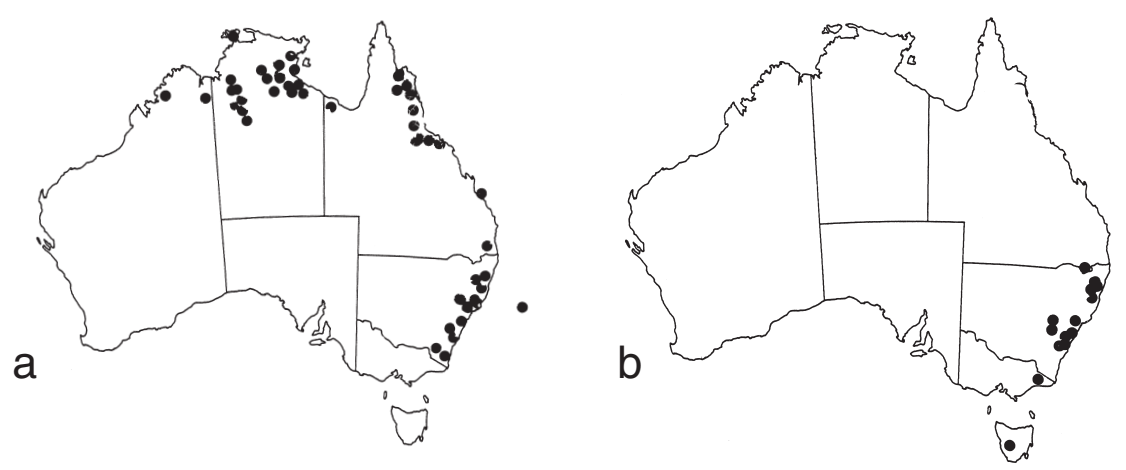

Fig. 5. a, Distribution of Isopterygium albescens in Australia; b, Distribution of Isopterygiopsis pulchellum in Australia. 
have been given varietal status, e.g. var. fulvum, var. minus, var. groutii, etc. but Crum and Anderson (1981) note that the species is extremely variable, and that it is useless to segregate such varieties.

There has been confusion in the identity of the species Isopterygium novae-valesiae Broth., considered an Australian endemic until these studies, as it has been known as either Isopterygium (Broth. 1900) or Taxithelium (Broth. 1908). While revising the Australian species of Taxithelium, the type collections from H-BR and isotypes from NSW of Isopterygium [Taxithelium] novae-valesiae were examined by Ramsay et al. (2002a) and again recently by Paulo Câmara at the Missouri Botanical Garden, who has been carrying out a world revision of the genus Taxithelium. Both confirm that the type specimens listed by W.W. Watts and held at H-BR and NSW do not contain any Taxithelium species. Isopterygium novae-valesiae has non-papillose cells while Taxithelium has pluripapillose cells. Brotherus, however, did allow for non-papillose species in his concept of Taxithelium, a view not currently accepted.

The lectotype specimen (Watts 1902) of Isopterygium novae-valesiae has non-papillose cells, and after careful examination, we have reduced it to synonymy with I. albescens. Specimens of this vary somewhat from other collections of I. albescens as recognised here. They are often pale yellow-green and have much longer setae and slightly larger more acuminate leaves than the general collection.

Many specimens from north-eastern New South Wales were examined and identified by Brotherus as Isopterygium candidum (Müll.Hal.) A.Jaeger in the 1890's. Most of the specimens from New South Wales with this name have been re-determined as I. minutirameum (now I. albescens). However, those from Lord Howe Island are correctly named as I. albescens.

\section{Isoptergiopsis}

Isopterygiopsis (Hedw.) Z.Iwats., J. Hattori Bot. Lab. 33: 379-380 (1970)

Type: Plagiothecium muellerianum Schimp.

Etymology: derived from the name Isopterygium (see above) and the Greek -opsis (appearance)in reference to the similarity between the two genera.

Plants dioicous or autoicous, medium sized to small, shiny; stems creeping, irregularly pinnately branched; in cross section of stem, epidermal cells large, thin-walled and often hyaline, or small and more or less thick-walled; central strand indistinct,. rhizoids papillose and axillary; pseudoparaphyllia absent; when present, gemmae occur as axillary fascicles of filamentous propagulae 3-7 cells long; annulus differentiated. Leaves erect to wide-spreading and weakly to distinctly complanate; narrowly lanceolate triangular, acuminate, entire. Setae long, capsules suberect, annulus 2 rows of cells, operculum bluntly low-conic. Peristome hypnoid.

Isopterygiopsis was described by Iwatsuki (1970) for species similar in appearance to Isopterygium in size, but different in having no pseudoparaphyllia on stems, large hyaline or thin-walled epidermal cells in stem cross-sections and axillary papillose rhizoids instead of smooth rhizoids arising below leaf insertion, filamentous propagules and having a differentiated annulus. It is more similar to Plagiothecium in characters of pseudoparaphyllia and propagulae, but differs in having non-decurrent leaf-bases 
(Iwatsuki 1987). As part of a revision of the genus Isopterygium for the Flora of Australia by us, the specimens for Isopterygium pulchellum (Hedw.) A.Jaeger = Isopterygiopsis pulchella (Hedw.) Iwats. were examined as its occurrence in Australia has been reported as doubtful' (Streimann \& Klazenga 2002). Recent studies of specimens and types of Isopterygium arachnoideum and I. subarachnoideum, now placed into synonymy with Isopterygiopsis pulchella (see below), confirm its presence in Australia.

Isopterygiopsis pulchella (Hedw.) Z.Iwats., J. Hattori Bot. Lab. 63: 450 (1987). Leskea pulchella Hedw., Sp. Musc. 220 (1801). Isopterygium pulchellum (Hedw.) A.Jaeger \& Sauerb., Ber. St. Gall. Naturw. Ges. 1876-77: 441 (1878).

Type: In silvis umbrosis Scotiae (Hedwig 1801).

Isopterygium arachnoideum Broth., Oefvers Finska Vetensk.-Soc. Foerh. 42: 112 (1900). Type: Australia, New South Wales, Richmond River, Teukombil (=Tuckumbil) Hunter's Scrub, on tree fern trunks. W.W. Watts 549, lectotype H-BR, isolectotype ( 4 specimens in NSW)[selected here]. syntype: Three mile scrub, tree fern trunks W.W. Watts 879 (NSW, H-BR). [Note W.W. Watts 587 in MEL is not a type, refer to Ramsay and Seur (1994)]

Isopterygium subarachnoideum Broth. Oefvers Finska Vetensk.-Soc. Foerh 42: 113 (1900). Type: Australia, New South Wales, Richmond River, Hunter's Scrub, on tree fern trunk, W.W. Watts 744, lectotype: H-BR; isolectotype: NSW [selected here]. No specimen of the syntype Watts 588 was found in H-BR or NSW.

Illustrations: Crum and Anderson, Mosses of eastern North America, vol. 2, fig 582 (1981); Ignatov \& Ignatov, Moss flora of the middle European Russia, vol. 2: fig 439 (2004); Ireland, Moss flora of the Maritime Provinces: fig. 357 (1982); Nyholm, Illustrated moss flora of Fennoscandia. II. Musci, fasc. 5: fig. 411 (1965) - all as Isopterygium pulchellum. Smith, The moss flora of Britain and Ireland, 2nd ed.: fig. 295. 9-11 (2004); Zhang \& Si, Hypnaceae. Moss flora of China, English Version: pl. 689 (2005) - both as Isopterygiopsis pulchellum.

Plants autoicous, small and slender in shiny, bright-green or yellow to greyish-green flat mats. Stems creeping, mostly unbranched with several arising at base of perichaetia, stem in cross section with epidermal cells not so large, with outer wall thin or slightly thickened and with an indistinct central strand. Branches numerous, often ascending; pseudoparaphyllia absent. Leaves usually not crowded, erect to wide-spreading and weakly to distinctly complanate, often secund at tips, $0.7-1.2 \mathrm{~mm}$ long, narrowly lanceolate-triangular, slenderly acuminate, not decurrent, less than $0.2 \mathrm{~mm}$ wide at base, entire, ecostate. Laminal cells linear in midleaf 35-70 $\mu \mathrm{m}$ x $5 \mu \mathrm{m}, 7-14: 1$ long as wide, cells scarcely differentiated at basal angles. Propagules occasionally present, axillary fusiform or cylindrical, 2-5 cells long. Perigonia numerous and usually present on lower stems. Perichaetia on stems. Perichaetial leaves erect, similar in size to leaves. Setae 8-16 mm long, orange or yellow, becoming orange-red; capsules suberect and nearly symmetric to inclined and asymmetric, oblong-cylindric, capsules mostly 1.0-1.5 mm., annulus of 2 rows of cells; operculum low-conical with a short rostrum; peristome hypnoid, endostome with non-perforate segments and single (sometimes paired) cilia. Spores $9-13 \mu \mathrm{m}$, minutely roughened. Chromosome numbers $n=10+m$, 10+2m, 22 (none Australian, Fritsch 1991). Fig. 6

Distributed, in North America, Europe, Asia, Africa, New Zealand and Australia (Queensland, New South Wales, Victoria, Tasmania). In N.S.W. most specimens occur 

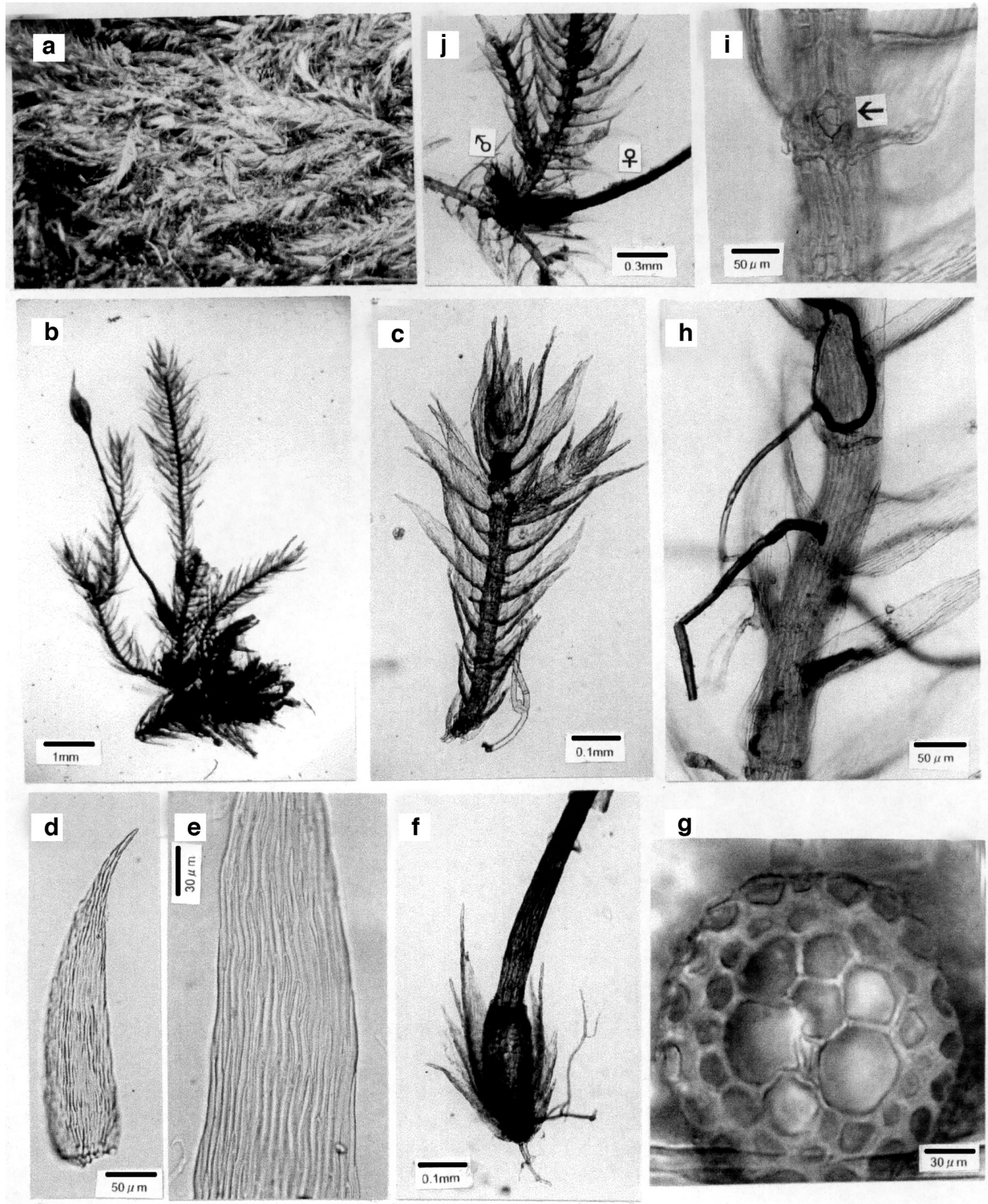

Fig. 6. Isopterygiopsis pulchella. a, plants; b, plant with sporophyte; c, branch; d, e, leaves; $\mathbf{f}$, perichaetium; $\mathbf{g}$, cross-section of stem; $\mathbf{h}$, branch with rhizoids; $\mathbf{i}$, branch with branch primordia (arrow); j, plant with male and female inflorescences. (all based on Australian material; a, c-e, \& g-j I.R. Telford, CANB; b \& f W.W. Watts 577, NSW; photographs by Z. Iwatsuki). 
on the trunks of tree ferns from sea level to subalpine in the Blue Mts. and on the coast and coastal ranges as far north as the Richmond River district and the Border Ranges between N.S.W. and Qld possibly as far north as Eungella National Park. In Tasmania it occurs mainly on wood or tree trunks in the west and south-west at altitudes below 300 m. Fig. 5

Selected Specimens: Australia: Queensland: McPherson Range, Coomera Range, I.R.Telford s.n. (CANB). New South Wales: Valley of Waters, Blue Mts, W.W. Watts 5434, 5435, 5436, 10471 (NSW); Woodford, Blue Mts, W.W. Watts 8275 (NSW); Brunswick River, W.W. Watts 1586, 1591(NSW), 4195 (MEL); Tuckombil, W.W. Watts 577 (as I. arachnoideum) 4912, 4913, 4908 (NSW), W.W. Watts 587 (as I. arachnoideum) (MEL); Ballina W.W. Watts 2874, 5849 (NSW); Stanwell Park W.W. Watts 8277 (NSW); Cambewarra W.W. Watts 6590, 9930, 9946 (NSW); Bulgong Heights W.W. Watts s.n., May 1916 (NSW 245517); Belmore Falls W.W. Watts 9822 (NSW); Nowra W.W. Watts 8268 (NSW); Tomerong W.W. Watts 6235, 6236 (NSW); “Kingwell”, Wyong W.W. Watts 9604, 9480, 8971, 8972, 9631, 9715, 9532, 9722 (NSW); Gladesville, Sydney W.W. Watts 9289 (NSW); Manly, Sydney W.W. Watts 6815, 6820 (NSW), Neutral Bay, Sydney W.W. Watts 8000 (NSW); Brindle Creek, Wiangarie S.F. H. Streimann s.n. (CANB); Dorrigo N.P. H. Streimann s.n. (CANB); Victoria: Mt Drummer, N.A.S. Wakefield s.n. (MEL 1031453); Tasmania: West Coast W.A. Weymouth 2793 (HO); Zeehan Railway, W.A. Weymouth 630 (HO); Recherche, W.A. Weymouth 2586, 2587, 2618, 2619 (HO).

The following key is provided to assist in identifying the now recognised Australian taxa that were formerly Isopterygium, i.e. Isopterygium, Isopterygiopsis and Austrohondaella.

1. Leaves acuminate with more or less serrulate apices; rhizoids smooth, arising between leaves on stem; pseudoparaphyllia filamentous; capsule curved, horizontal or pendulous; annulus absent, operculum bluntly apiculate or curved rostrate Isopterygium albescens

1. Leaves with entire apices; rhizoids papillose, arising from leaf axils; pseudoparaphyllia absent or foliose; capsule erect or suberect to inclined; annulus present; operculum low conic or blunt

2. In section, stems with large thin-walled epidermal cells, thick-walled outer cortex, thin-walled inner cells, central strand present; capsule suberect to inclined, operculum low conic; pseudoparaphyllia absent Isopterygiopsis pulchella

2. In section, stem with small epidermal cells, an outer sclerodermis and inner thin walled cortical cells, central strand absent; capsule erect, symmetrical; operculum bluntly conic; pseudoparaphyllia foliose Austrohondaella limata

\section{New records for Australia}

Among the Australian collections examined during this study, the following specimens of Pseudotaxiphyllum pohliicarpum (Hypnaceae) were discovered and are clearly identified by the Pohlia-like gemmae (Iwatsuki 1987, Noguchi 1994). The earliest collection is that of Watts in 1916, and a more recent collection is that of H. Streimann in 1991. These are the first records of this species for Australia.

Pseudotaxiphyllum pohliicarpum (Sull. \& Lesq.) Z.Iwats., J. Hattori Bot. Lab. 63: 449 (1987). Hypnum pohliaecarpum Sull. \& Lesq., Proc. Am. Ac. Art Sc. 4: 280 (1859). Isopterygium pohliicarpum (Sull. \& Lesq.) A.Jaeger, Ber. Thätigk. St. Gallischen Naturwiss. Ges. 1876-77: 442 (1878). 
Specimens examined: Australia: New South Wales: Northern Tablelands: Weeping Rocks, New England National Park, $72 \mathrm{~km}$ of Armidale, Nothofagus-Elaeocarpus dominated forest, at base of escarpment, on shaded rock face, H. Streimann 47736 (CANB, NY). Central Coast: Sassafras Gully, Springwood W.W. Watts 10917 Jan 1916 (NSW 245625).

Distribution: Japan, China, Vietnam, Laos, Thailand, Philippines, new to Australia.

\section{Names transferred elsewhere or specimens not found}

Isopterygium caespitulosum Paris, Index Bryol. Suppl. 218 (1900), nom. nud. = Taxicaulis caespitulosus Müll.Hal., nom. nud. Not found.

Isopterygium nitens E.B.Bartram. A specimen labelled type ('co-type') with this name at NSW collected in Western Australia was redetermined by Bartram as Sauloma zetterstedtii (Müll.Hal.) A.Jaeger. Subsequently in a note J. H. Willis says he preferred to treat it as the 'western form of Sauloma tenella (Hook.f. \& Wilson) Mitt.'

Isopterygium pseudosubulatum (Müll.Hal.) Paris, Ind. Bryol. Suppl. 220 (1900) (Taxicaulis 1887) is a non Australian taxon (see Streimann \& Klazenga, 2002, p. 198). A Whitelegge specimen bearing this name is held at NY (W. Buck, pers. comm.): T.W. Whitelegge, 1886 (n.v.).

Isopterygium teysmannii Broth. = Taxiphyllum taxirameum (Mitt.) M.Fleisch.

Hypnum teysmannii Sande Lac., Bryologia Javanica 2: 192, 290. 1868. Isopterygium teysmannii (Sande Lac.) A. Jaeger, Ber. Thätigk. St. Gallischen Naturwiss. Ges. 1876-1877: 433 (1878).

Isopterygium umbillicatulum Mitt., Trans. \& Proc. Roy. Soc. Victoria 19:86 (1882), nom. nud. = Ectropothecium sp.

Isopterygium viridepallidus Müll.Hal. ex W.Forsyth, Proc. Linn. Soc. New South Wales 24: 683 (1900), nom. nud. Not found.

Isopterygium walterianum (Hampe) Mitt., Trans. Roy. Soc. Victoria 19:86 (1882). Hypnum walterianum (Hampe) A.Jaeger, Ber. Thätigk. St. Gallischen Naturwiss. Ges. 1877-78: 320 (1880). (Gen. Sp. Musc. 2: 584). Type: Victoria: Mt. Macedon, Walter = Hypnum cupressiforme Hedw. var. mossmannianum (Müll.Hal.) Ando.

\section{Acknowledgments}

We wish to acknowledge and thank the various herbaria CANB, H-BR, HO, MEL, $\mathrm{NICH}, \mathrm{NSW}, \mathrm{NY}$ for the loan of many specimens (including type specimens) and access to distribution data. Paulo Câmara at the Missouri Botanical Garden checked the type collections of Isopterygium novae-valesiae on loan from H-BR for us. Peter Wilson kindly supplied a translation of the Latin description of Isopterygium novaevalesiae. Elizabeth Brown assisted with cutting stem sections. Alison Downing was helpful in checking some specimens for H Ramsay. Allan Fife kindly provided access to unpublished information regarding the species in New Zealand. 


\section{References}

Bartram EB (1972) Mosses of the Philippines. Philippine Journal of Science 68: 437. (Bureau of Printing, Manila)

Brotherus VF (1900) Some new species of Australian mosses described. IV. Oefversigt af Förhandlingar, Finska Vetenskaps-Societeten 42: 113.

Brotherus VF (1908) Musci. P. 1080 in Engler HGA \& Prantl KAE (eds) Die näturlichen Pflanzenfamilien, vol. 1(3). (Wilhelm Engelmann, Leipzig)

Crum HA \& Anderson LE (1981) Mosses of eastern North America, vol. 2, 665-1328. (Columbia University Press, New York.)

Dalton PJ, Seppelt RD \& Buchanan AM (1991) An annotated checklist of Tasmanian mosses. Pp.15-32 in Banks MR et. al. (eds) Aspects of Tasmanian Botany- A Tribute to Winifred Curtis. (Royal Society of Tasmania, Hobart)

Dozy F \& Molkenboer JH (1868) Bryologia Javanica, vol. II. Fasc. 58-60. (EJ Brill, Leiden)

Fife A (1985) Biosystematics of the cryptogamic flora of New Zealand: Bryophytes. New Zealand Journal of Botany 23: 645-662.

Fritsch R (1991) Index to bryophyte chromosome counts. Bryophytorum Bibliotheca 40: 1-352.

Goffinet B \& Buck WR (2004) Systematics of the Bryophyta (mosses): from molecules to a revised classification. Monographs on Systematic Botany 98: 205-239.

Goldblatt P \& Johnson DE (1994) Index to Plant Chromosome Numbers 1990-1991. Monographs on Systematic Botany 51:3-12. (Missouri Botanical Garden Press, St Louis, Missouri)

Goldblatt P \& Johnson DE (1998) Index to Plant Chromosome Numbers 1994-1995. Monographs on Systematic Botany 69: 3-6. ( Missouri Botanical Garden Press, St Louis, Missouri)

Goldblatt P \& Johnson DE (2003) Index to Plant Chromosome Numbers 1998-2000. Monographs on Systematic Botany 94: 3-7. ( Missouri Botanical Garden Press, St Louis, Missouri)

Ignatov MS \& Ignatov EA (2004) Moss Flora of Middle European Russia, vol. 2: 612-960. (KMK Scientific Press Ltd Moscow)

Ireland R (1982) Moss flora of the maritime provinces. 738 pp.(National Museum of Canada, Ottawa)

Iwatsuki Z (1970) A revision of Plagiothecium and its related genera from Japan and her adjacent regions Journal of the Hattori Botanical Laboratory 33: 331-380.

Iwatsuki Z (1987) Notes on Isopterygium Mitt. (Plagiotheciaceae). Journal of the Hattori Botanical Laboratory 63: 445-451.

Iwatsuki Z, Ramsay HP \& Fife AJ (2009) A new genus Austrohondaella (Bryopsida, Hypnaceae) in Australasia. Telopea 12(3): 361-369.

Noguchi A (1994) Illustrated Moss Flora of Japan, part 5. (Hattori Botanical Laboratory, Nichinan)

Nyholm E (1965) Illustrated moss flora of Fennoscandia, fasc. 5 (CWK Gleerup, Lund)

Ramsay H P \& Seur J (1994) Register of Type Specimens of mosses in Australian Herbaria. Flora of Australia supplementary series number 2. (Australian Biological Resources Study, Canberra)

Ramsay HP, Schofield WB \& Tan BC (2002) The genus Taxithelium (Bryopsida, Sematophyllaceae) in Australia. Australian Systematic Botany 15: 1-14.

Scott GAM \& Stone IG (1976) The mosses of southern Australia. 495 pp. (Academic Press, London)

Smith AJE (2004) The moss flora of Britain and Ireland, 2nd edition. 1012 pp. (Cambridge University Press, Cambridge)

Streimann H \& Klazenga N (2002) Catalogue of Australian mosses. 259 pp. (Australian Biological Resources Study, Canberra)

Zhang Man-Xiang \& Si He (2005) Hypnaceae. Pp. 80-260 in Wu PC, Crosby MR \& Si H (eds) Moss Flora of China, English version, vol. 8: Sematophyllaceae-Polytrichaceae. (Science Press, Beijing) 